\title{
Direct Digital Control in a Complex of Software Design of Digital Control Systems
}

\author{
Sergei Verteshev, Vladimir Konevtsov \\ Pskov State University, \\ Faculty of Computer Science and Electrical Power Engineering. \\ Address: Leo Tolstoi Street 4, Pskov, Russia
}

\begin{abstract}
This article provides the functionality of creating direct digital control devices in the computer-aided design of digital automatic control systems (CAD of digital ACS), in a complex of software design of digital control systems (SDSDC complex) for automated process control systems. Technical tools are defined by the international standard IEC 61131-1: 2003 (Part 1: General data). The possibility of implementing SDSDC complex in direct digital control, singlecycle and multi-cycle ladder diagrams, identification of objects of management and synthesis of digital controllers in comparison with the international standard IEC 61131-3: 2003 (Part 3: Programming Languages) are evaluated. Users' productivity is estimated as well as the possibility of its separation between the users at different stages of the design of digital systems of automatic control is assessed.
\end{abstract}

Keywords: closed loop digital control, corrective digital device, direct digital control, proportional-integral-derivative controller.

\section{DIGITAL CONTROL CHANNEL}

Direct digital control can be used to perform a wide variety of tasks [1]:

- stabilization - ensuring equality of the controlled variable with a given accuracy and constant over time given value;

- program control - ensuring equality of the controlled variable with a given accuracy and previously known function of time;

- tracing control - providing "proximity" of the controlled variable to previously unknown function of any form of time;

- extreme control - retention of the criterion of work quality of the system in the field of proximity to previously unknown and changing in space controlled or specified variable to extreme value of a control quality criterion;

- optimal control - transfer from one state to another with extreme value of selected quality indicators.

The object is controlled by a digital control channel, comprising elements (blocks) of signal processing:

1. Input of values of the controlled variable from the sensor;

2. Input of channel status variables (manual, automatic or program mode, the position of executive body);

3. scaling controlled variable values, the variable of position of the executive body;

4. filtration;
5. verification of signals on the limit values and the rate of change;

6. calculation of control (regulation) error;

7. error limitation and control;

8. calculation of a manipulated variable;

9. the restriction and control of a manipulated variable, ensuring smooth (unstressed) transients in a closed control loop;

10. the zoom of a manipulated variable;

11. output of values of a manipulated variable on the actuator;

12. the digital control channel may comprise units of software and logic control (switches, commutators, signal combiners, etc.) to communicate with other channels and systems.

Synthesis of digital control channel structure is the most objective intuition, rather than "pure" mathematical problem that cannot be solved as standard. Most of the existing "classical" methods of calculation and channel settings are focused on the synthesis of block 8), i.e. algorithm for calculating the manipulated variable (equalizer).

\section{CORRECTIVE DIGITAL DEVICES}

By corrective device $[2,3,4]$ is implied mathematical dependence, which can be used to achieve the desired behavior of the managed object. A special case of a corrective device is, for example, a conventional proportional-integral-derivative (PID) controller [5,6,7]. Corrective device synthesis is made according to the principle implemented [8-16]:

- direct control, 
- feedback control,

- combined control.

The control problem is to achieve with a certain degree of accuracy (quality) the equality between the reference variable $\mathrm{W}(\mathrm{z})$ and controlled variable $\mathrm{Y}(\mathrm{z})$ in the presence of interference $\mathrm{V}(\mathrm{z})$.

In direct management, based on the requirements

$$
\mathrm{Y}(\mathrm{z})=\mathrm{W}(\mathrm{z})
$$

transfer function of the corrective device $\mathrm{D}(\mathrm{z})$ is equal to the inverse transfer function of the object $\mathrm{G}(\mathrm{z})$

$$
\mathrm{D}(\mathrm{z})=1 / \mathrm{G}(\mathrm{z})
$$

Direct control principle (the principle of precession or compensation) can be used in cases when in the object controlled:

- there is no hindrance or the values of the hindrance signal are measurable;

- the transfer function of the object corresponds to the entire working range of control action change;

- there are no restrictions in the digital control channel (non-linearity).

For real objects, these conditions are ideal, so the principle of feedback control (the principle of deviation) has got practical application. This principle allows to satisfy the condition (1) with required accuracy, regardless of the cause of the error in a closed control loop. A closed loop digital control generally comprises:

- quantizers of a reference variable $\mathrm{w}(\mathrm{t})$, a manipulated variable $\mathrm{u}(\mathrm{k})$ and a controlled variable $\mathrm{y}(\mathrm{t})$;

- digital corrective device $\mathrm{D}(\mathrm{z})$ with the transfer function:

$$
\begin{aligned}
& \mathrm{D}(\mathrm{z})=\mathrm{U}(\mathrm{z}) / \mathrm{E}(\mathrm{z})= \\
& =\left(\mathrm{d}_{0}+\mathrm{d}_{1} \mathrm{z}^{-1}+\ldots+\mathrm{d}_{\mathrm{n}} \mathrm{z}^{-\mathrm{n}}\right) /, \\
& /\left(1+\mathrm{c}_{1} \mathrm{z}^{-1}+\ldots+\mathrm{c}_{\mathrm{n}} \mathrm{z}^{-\mathrm{n}}\right)
\end{aligned}
$$

where $\mathrm{U}(\mathrm{z}), \mathrm{E}(\mathrm{z})$ - images of the manipulated variable signals $\mathrm{u}(\mathrm{k})$ and deviation $\mathrm{e}(\mathrm{k})$ (control error);

- control object $\mathrm{G}(\mathrm{z})$, representing a discrete latch conversion $\mathrm{F}(\mathrm{p})=(1-\exp (-\mathrm{pT})) / \mathrm{p}$ and continuous transfer function of the object $\mathrm{G}(\mathrm{p})$ :

$$
\mathrm{G}(\mathrm{z})=\mathrm{Y}(\mathrm{z}) / \mathrm{U}(\mathrm{z})=\left(1-\mathrm{z}^{-1}\right) \mathrm{Z}\{\mathrm{G}(\mathrm{p}) / \mathrm{p}\},
$$

where $\mathrm{Y}(\mathrm{z})$ - image of the controlled variable signal $\mathrm{y}(\mathrm{t})$.

The order and parameters of the corrective device are selected according to dependencies defined by the applicable method of the synthesis of this device taking into account the properties of the object of control, restrictions, criteria for quality control. The corrective device conventionally used in practice is a PID controller and its modifications, represented by the differential equation:

$$
\mathrm{u}(\mathrm{t})=\mathrm{K}\left[\mathrm{e}(\mathrm{t})+\frac{1}{\mathrm{~T}_{\mathrm{I}}} \int \mathrm{e}(\mathrm{t}) \mathrm{d} \tau+\mathrm{T}_{\mathrm{d}}(\mathrm{de}(\mathrm{t}) / \mathrm{dt})\right]
$$

where $\mathrm{K}$ - coefficient of controller gain;

$\mathrm{T}_{\mathrm{I}}$ - integration time (integral action);

Td - derivation time (precession);

$\mathrm{e}(\mathrm{t})$ - control error (deviation);

$\mathrm{e}(\mathrm{t})=\mathrm{w}(\mathrm{t})-\mathrm{y}(\mathrm{t})$

$\mathrm{w}(\mathrm{t})$ - reference variable;

$\mathrm{y}(\mathrm{t})$ - controlled variable.

\section{Closed-loop digital control}

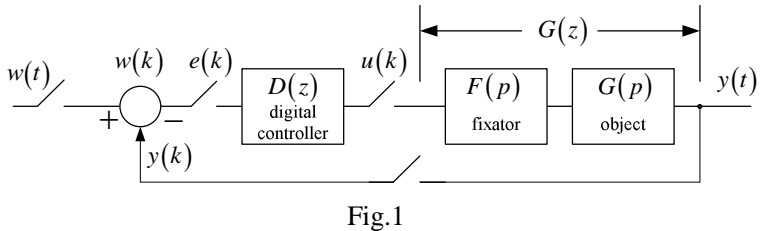

The differential equation (5) can be converted into the form of the equation of differencies by differentiating and replacing the differential relations by difference:

$\mathrm{du}(\mathrm{t}) / \mathrm{dt}=$

$=K\left[\operatorname{de}(\mathrm{t}) / \mathrm{dt}+1 / \mathrm{T}_{\mathrm{I}} \cdot \mathrm{e}(\mathrm{t})+\mathrm{T}_{\mathrm{d}}\left(\mathrm{d}^{2} \mathrm{e}(\mathrm{t}) / \mathrm{dt}^{2}\right)\right]$,

after replacing the first and second derivatives by the first and second differences:

$$
\begin{aligned}
& \mathrm{de}(\mathrm{t}) / \mathrm{dt} \approx \Delta \mathrm{e}(\mathrm{k})=(\mathrm{e}(\mathrm{kT})-\mathrm{e}(\mathrm{kT}-\mathrm{T})) / \mathrm{T} \\
& \mathrm{d}^{2} \mathrm{e}(\mathrm{t}) / \mathrm{dt}^{2} \approx \Delta^{2} \mathrm{e}(\mathrm{k})= \\
& =(\mathrm{e}(\mathrm{kT})-2 \mathrm{e}(\mathrm{kT}-\mathrm{T})+\mathrm{e}(\mathrm{kT}-2 \mathrm{~T})) / \mathrm{T}^{2} \\
& \mathrm{du}(\mathrm{t}) / \mathrm{dt} \approx \Delta \mathrm{u}(\mathrm{t})=(\mathrm{u}(\mathrm{kT})-\mathrm{u}(\mathrm{kT}-\mathrm{T})) / \mathrm{T}
\end{aligned}
$$


Environment. Technology. Resources, Rezekne, Latvia

where $\mathrm{T}$ - period of discreteness chosen small enough, based on the inertia of the controlled object [27].

After substituting the right-hand sides (8) - (10) in (7) instead of corresponding differential relationship with the replacement of real time $\mathrm{kT}$ by the relative $\mathrm{k}$, $\mathrm{k}=0,1,2, \ldots$ difference form of the PID controller is got:

$$
\begin{aligned}
& \mathrm{u}(\mathrm{k})=\mathrm{u}(\mathrm{k}-1)+ \\
& +\mathrm{K}\left[\mathrm{e}(\mathrm{k})-\mathrm{e}(\mathrm{k}-1)+\mathrm{e}(\mathrm{k}) \mathrm{T} / \mathrm{T}_{\mathrm{I}}+\right. \\
& +\mathrm{Td} / \mathrm{T}(\mathrm{e}(\mathrm{k})-2 \mathrm{e}(\mathrm{k}-1)+\mathrm{e}(\mathrm{k}-2))]
\end{aligned}
$$

After grouping the values of the error with respect to timings

$\mathrm{k}, \mathrm{k}-1, \mathrm{k}-2$ the final form of the difference equation $\mathrm{f}$ the PID controller is got:

$$
\begin{aligned}
\mathrm{u}(\mathrm{k}) & =\mathrm{u}(\mathrm{k}-1)+\mathrm{d}_{0} \mathrm{e}(\mathrm{k})+\mathrm{d}_{1} \mathrm{e}(\mathrm{k}-1)+\mathrm{d}_{2} \mathrm{e}(\mathrm{k}-2) \\
\mathrm{d}_{0} & =\mathrm{K}\left(1+\mathrm{T} / \mathrm{T}_{\mathrm{I}}+\mathrm{T}_{\mathrm{d}} / \mathrm{T}\right) \\
\mathrm{d}_{1} & =-\mathrm{K}\left(1+2 \mathrm{~T}_{\mathrm{d}} / \mathrm{T}\right) \\
\mathrm{d}_{2} & =\mathrm{K}\left(\mathrm{T}_{\mathrm{d}} / \mathrm{T}\right)
\end{aligned}
$$

From (11) the transfer function of a digital equivalent of the analog controller can be obtained, using the theorem of z-transform delay:

$$
\begin{aligned}
& \mathrm{D}(\mathrm{z})=\mathrm{U}(\mathrm{z}) / \mathrm{E}(\mathrm{z})= \\
& =\left(\mathrm{d}_{0}+\mathrm{d}_{1} \mathrm{z}^{-1}+\mathrm{d}_{2} \mathrm{z}^{-2}\right) /\left(1-\mathrm{z}^{-1}\right)
\end{aligned}
$$

If not to take into account the expressions (12)(14), the form of writing (15) does not indicate that it represents the PID controller in the conventional sense, because the PD controller has the same discrete transfer function only with other values of the numerator coefficients in (15), obtained from (12) - (14) at $\mathrm{T}_{\mathrm{I}} \rightarrow \infty$ :

$$
\begin{aligned}
& \mathrm{d}_{0}=\mathrm{K}\left(1+\mathrm{T}_{\mathrm{d}} / \mathrm{T}\right) ; \\
& \mathrm{d}_{1}=-\mathrm{K}\left(1+2 \mathrm{~T}_{\mathrm{d}} / \mathrm{T}\right) ; \\
& \mathrm{d}_{2}=\mathrm{K}\left(\mathrm{T}_{\mathrm{d}} / \mathrm{T}\right) .
\end{aligned}
$$

From the expressions (11)-(14) a digital PI controller can be obtained at $\mathrm{T}_{\mathrm{d}} \rightarrow 0$ :

$$
\begin{aligned}
\mathrm{D}(\mathrm{z}) & =\mathrm{U}(\mathrm{z}) / \mathrm{E}(\mathrm{z})=\left(\mathrm{d}_{0}+\mathrm{d}_{1} \mathrm{z}^{-1}\right) /\left(1-\mathrm{z}^{-1}\right) \\
\mathrm{d}_{0} & =\mathrm{K}\left(1+\mathrm{T} / \mathrm{T}_{\mathrm{I}}\right)
\end{aligned}
$$

$$
\mathrm{d}_{1}=-\mathrm{K}
$$

Similarly, $\mathrm{P}$ controller is shaped like a PI controller at $\mathrm{T}_{\mathrm{I}} \rightarrow \infty$, in which $\mathrm{d}_{0}=-\mathrm{d}_{1}=\mathrm{K}$.

A variety of digital controllers whose forms and parameters are removed from the molds and parameters of traditional analog controllers is immense. They were derived based on various objects' properties and signals acting on the control circuit. Thus, with significant changes in the reference variable the algorithm (11) will lead to a shock impulse actions on the object, which may cause unwanted transients in a closed control loop. To eliminate this effect suggested the controller structure is suggested in which differentiation of the signal of the reference variable is eliminated by replacing the reference variable differential component of the error by differential component of the controlled variable:

$$
\begin{aligned}
& \mathrm{du}(\mathrm{t}) / \mathrm{dt}= \\
& =\mathrm{K}\left[\mathrm{dy}(\mathrm{t}) / \mathrm{dt}+1 / \mathrm{T}_{\mathrm{I}} \mathrm{e}(\mathrm{t})+\mathrm{Td}\left(\mathrm{d}^{2} \mathrm{y}(\mathrm{t}) / \mathrm{dt}^{2}\right)\right],
\end{aligned}
$$

therefore

$$
\begin{aligned}
& \mathrm{u}(\mathrm{k})=\mathrm{u}(\mathrm{k}-1)+\mathrm{d}_{0} \mathrm{y}(\mathrm{k})+\mathrm{d}_{1} \mathrm{y}(\mathrm{k}-1) \\
& ++\mathrm{d}_{2} \mathrm{y}(\mathrm{k}-2)+\mathrm{d}_{3} \mathrm{w}(\mathrm{k}) \\
& \mathrm{d}_{0}=-\mathrm{K}\left(1+\mathrm{T} / \mathrm{T}_{\mathrm{I}}+\mathrm{T}_{\mathrm{d}} / \mathrm{T}\right) \\
& \mathrm{d}_{1}=\mathrm{K}\left(1+2 \mathrm{~T}_{\mathrm{d}} / \mathrm{T}\right) \\
& \mathrm{d}_{2}=-\mathrm{K} \mathrm{T}_{\mathrm{d}} / \mathrm{T} \\
& \mathrm{d}_{3}=-\mathrm{K}\left(\mathrm{T}_{\mathrm{d}} / \mathrm{T}\right)
\end{aligned}
$$

A block diagram of the connection to the object of equivalent (22) analog controller is shown in Fig. 2. It shows that the abrupt reference variable "is softened" by integrating the error, on the one hand, and the smoothing action of the object, on the other hand, allowing to avoid strong throws of values of differential and proportional part by the reference variable signal.

These effects often occur during channel transitions from manual to automatic or program mode. If the object does not possess adequate smoothing properties, it is possible to use a low pass filter in the differentiation circuit (Fig. 3).

Depending on the properties of the actuator position algorithms (to control actuators that do not have memory) and incremental or speed algorithms of controllers (to control actuators having memory), i.e. able to integrate (stepper motors, valves, integrating amplifiers), are varied.

From (11) we obtain an incremental algorithm of PID-controller: 


$$
\begin{aligned}
& \Delta \mathrm{u}(\mathrm{k})=\mathrm{u}(\mathrm{k})-\mathrm{u}(\mathrm{k}-1)= \\
& =\mathrm{d}_{0} \mathrm{e}(\mathrm{k})+\mathrm{d}_{1} \mathrm{e}(\mathrm{k}-1)+\mathrm{d}_{2} \mathrm{e}(\mathrm{k}-2)
\end{aligned}
$$

Algorithms of digital controllers whose structures and parameters are determined on the basis of approximation of transfer functions of objects by inertia and integrating links with delay (ZieglerNichols [10] Dalin [7], Kalman [7]) are known.

In practice, there are objects that have high inertia.

For example, it may take several minutes to change the temperature in the fermenter medium [8] of 50 cubic meters. One can use a two-position controller with insensitivity to manage a similar subject:

$$
\mathrm{u}(\mathrm{k})=\left\{\begin{array}{lc}
\mathrm{U} 1 & \text { at }(\mathrm{w}(\mathrm{k})-\Delta \mathrm{w})>\mathrm{y}(\mathrm{k}) \\
\mathrm{U} 2 & \text { at }(\mathrm{w}(\mathrm{k})+\Delta \mathrm{w})<\mathrm{y}(\mathrm{k}) \\
\mathrm{u}(\mathrm{k}-1) & \\
\text { at }(\mathrm{w}(\mathrm{k})-\Delta \mathrm{w}) \leq \mathrm{y}(\mathrm{k}) \leq(\mathrm{w}(\mathrm{k})+\Delta \mathrm{w}),
\end{array}\right.
$$

where $\mathrm{u}(\mathrm{k})$ - the value of the manipulated variable;

$\mathrm{w}(\mathrm{k})$ - the value of the reference variable;

$\mathrm{y}(\mathrm{k})$ - the value of the controlled variable;

$\Delta \mathrm{w}$ - dead zone;

\section{Control contour and «smoothing by the object»}
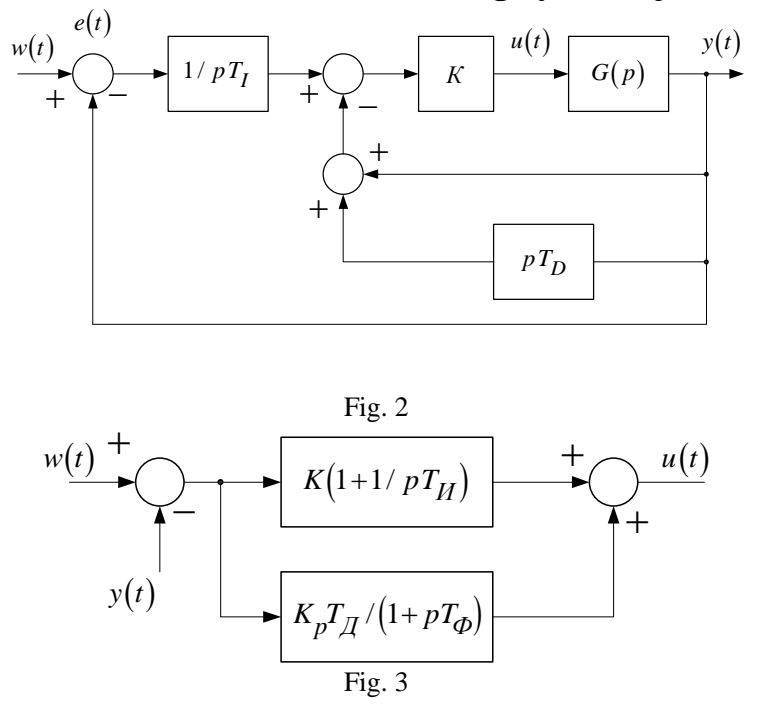

$\mathrm{U} 1, \mathrm{U} 2$ - the values of the manipulated variable outside the dead zone;

$\mathrm{u}(\mathrm{k}-1)$ - the value of the manipulated variable in the preceding control cycle.

The manipulated variable (28) can be output through the on-off actuators. In this case, U1 and U2 are the inverse logic signal values.

There is a class of digital controllers, whose structures correspond to the transfer function (3) and are calculated not from the traditional concepts and methods of tuning digital PID controllers and presentation of object properties in the form of a continuous transfer function. These methods are derived from the representation of the object properties in the form of a differential equation with delay d:

$y(k)=-\left[\sum_{i=1}^{m} a i \cdot y(k-i)+\sum_{i=0}^{n} b j \cdot u(k-i-d)\right](29)$

or in the form of discrete transfer function:

$\mathrm{G}(\mathrm{z})=\mathrm{Y}(\mathrm{z}) / \mathrm{U}(\mathrm{z})=$

$=\left(\mathrm{b}_{0}+\mathrm{b}_{1} \mathrm{z}^{-1}+\ldots+\mathrm{b}_{\mathrm{m}} \mathrm{z}^{-\mathrm{m}}\right) \mathrm{z}^{-\mathrm{d}} /$

$/\left(1+\mathrm{a}_{1} \mathrm{z}^{-1}+\ldots+\mathrm{a}_{\mathrm{m}} \mathrm{z}^{-\mathrm{m}}\right)$

Only arithmetic operations are used in the considered algorithms of digital controllers. Relations and logical operations usually show a variability of controller or channel structure, the presence of nonlinearities, etc. For example, the algorithm [6]:

$$
\Delta \mathrm{u}(\mathrm{k})=\left\{\begin{array}{l}
\mathrm{K}[\mathrm{e}(\mathrm{k})-\mathrm{e}(\mathrm{k}-1)]+\mathrm{K} \cdot \mathrm{T} \cdot \mathrm{e}(\mathrm{k}) / \mathrm{T}_{\mathrm{I}} \\
\text { at } \quad|\mathrm{e}(\mathrm{k})|-|\mathrm{e}(\mathrm{k}-1)| \geq 0 \\
\mathrm{~K} \cdot \mathrm{T} / \mathrm{T}_{\mathrm{I}} \cdot \mathrm{e}(\mathrm{k}) \\
\text { at }(|\mathrm{e}(\mathrm{k})|-|\mathrm{e}(\mathrm{k}-1)|<0) \wedge(|\mathrm{e}(\mathrm{k})|>\varepsilon)
\end{array}\right.
$$

has a variable structure depending on the nature of changes in the control error: if the absolute value of the control error is reduced, only the integral part of the controller calculating the manipulated variable is used, otherwise, if the absolute value of the control error increases, the proportional component of the controller to calculate the manipulated variable is used.

Piecewise-linear relationship

$$
\mathrm{u}(\mathrm{k})=\left\{\begin{array}{l}
\left|\mathrm{U}_{\mathrm{m}}\right| \text { Sign } \mathrm{e}(\mathrm{k}) \text { at }|\mathrm{e}(\mathrm{k})| \geq \varepsilon \\
0 \text { at } \mathrm{t}_{1}<\mathrm{t}<\left(\mathrm{t}_{1}+\Delta \mathrm{t}\right) \\
\mathrm{U}_{1} \text { at } \mathrm{t}>\left(\mathrm{t}_{1}+\Delta \mathrm{t}\right) \\
\mathrm{u}(\mathrm{k}-1)+\mathrm{d}_{0} \mathrm{e}(\mathrm{k})+\mathrm{d}_{1} \mathrm{e}(\mathrm{k}-1)+\mathrm{d}_{2} \mathrm{e}(\mathrm{k}-2) \\
\text { at } \mathrm{t}>\mathrm{t}_{2},
\end{array}\right.
$$

where $\mathrm{U}_{\mathrm{m}}$ - the maximum value of the manipulated variable;

$\varepsilon$ - the absolute value of the error;

$t_{1}$ - the duration of the forced regime; 
$\Delta t$ - pause duration;

$t_{2}$ - controller launch;

$U_{1}$ - the value of the manipulated variable before turning the PID controller can be used to implement the forced (relay) modes in the control loop with significant changes in the reference variable.

When handling control loop (manual, program, automatic modes) it is necessary to shock-free switching control circuit (controller channel compensation):

$$
\begin{aligned}
& \mathrm{Y}_{1}=\left\{\begin{array}{l}
1(\mathrm{~mm}=0) \wedge(\mathrm{pm}=0) \text { auto mode } \\
0 \text { otherwise manual or program mode }
\end{array}\right. \\
& Y_{2}=\bar{Y}_{1}
\end{aligned}
$$$$
\mathrm{Y}_{3}=\left\{\begin{array}{l}
\text { pmm at }=\mathrm{mm} \\
\text { papm at }(\mathrm{mm}=0) \wedge(\mathrm{pm}=1) \\
\mathrm{a}=\left\{\begin{array}{l}
\mathrm{Y}_{3}(0)+\Delta \mathrm{K} \mid \mathrm{e}(\mathrm{k})- \\
-\mathrm{e}_{0} \mid \operatorname{Sign~} \mathrm{e}(\mathrm{k}) \text { at } \mathrm{e}(\mathrm{k})>\mathrm{e}_{0} \\
\mathrm{Y}(\mathrm{k}-1) \text { otherwise }
\end{array}\right.
\end{array}\right.
$$

$$
\mathrm{Y}_{4}=\left\{\begin{array}{l}
\mathrm{X}_{1}(\mathrm{k}) \text { at } \mathrm{mm}=1 \\
\mathrm{X}_{2}(\mathrm{k}) \text { at }(\mathrm{pm}=1) \wedge(\mathrm{mm}=1) \\
\mathrm{Y}_{0} \text { otherwise }
\end{array}\right.
$$

where $\quad \mathrm{mm}-$ manual mode $(\mathrm{mm}=1)$; $\mathrm{pm}$ - program mode $(\mathrm{pm}=1)$;

pmm - the position of the actuator in the manual mode;

papm - the position of the actuator in the program mode;

$\mathrm{X}_{1}(\mathrm{k})$ - the controlled variable in the manual mode;

$\mathrm{X}_{2}(\mathrm{k})$ - the controlled variable in the program mode;

$\mathrm{Y}(\mathrm{k}-1)$ - the manipulated variable in the automatic mode;

$\mathrm{e}(\mathrm{k})$ - control error;

$\mathrm{e}_{0}$ - permissible control error;

$\Delta \mathrm{K}$ - increment compensation error;

$\mathrm{Y}_{3}(0)$ - the initial value of the compensation channel output;

$\mathrm{Y}_{1}$ - automatic mode;

$\mathrm{Y}_{2}$ - manual mode;

$\mathrm{Y}_{3}$ - the position of the actuator in the manual or program mode or the value of the manipulated variable;

$\mathrm{Y}_{4}$ - the value of the controlled variable or control task.

\section{CONCLUSION}

The paper provides the mathematical description of direct digital control oriented on its program implementation in the SDSDC complex. This approach allows to design and create systems of direct digital control with ampler functional capabilities than it is implied by the requirements of the IEC international standard 611-31-3. So, the program implementation of control in the SDSDC complex provides the creation of controllers' compensation channels and PID - controllers with and without a hysteresis.

\section{ACKNOWLEDGEMENTS}

The authors wish to express their sincere thanks to Tatyana Klets, Deputy Dean of Engineering and Construction Technologies Faculty of Pskov State University, for her invaluable foreign language assistance and supportive comments.

\section{REFERENCES}

[1] Волик Б.Г., Буянов Б.Б., Лубков Н.В. Методы анализа и синтеза структур управляющих систем. -М.: Энергоатомиздат, 1988, с. 296.

[2] Волгин Л.Н. Элементы теории управляющих машин.- М.: Советское радио, 1962 , с. 162

[3] Волгин ЛН Оптимальное дискретное управление динамическими системами. - М.: Наука, 1986, с. 240.

[4] Федотов С.М., Литвинов А.П. Автоматические системы с цифровыми управляющими машинами (теория и практика).- М., Ленинград: Энергия, 1965, с. 223.

[5] Емельянов С.В. Матич Б.П., Костылева Н.Е. Универсальная унифицированная система управления переменной структуры.- Приборы и системы управления, 1973, №12, с. 1-3, 1974, №1, c. 12-13.

[6] Unbehauen H., Böttiger F. Regelalgorithmen für Prozessrechner.- PDV-Berichte, 1974, №26, s. 108.

[7] Chiu K.C., Corripio A.B., Smith C.L. Digital Control Algorithms: Part I Dahlin-Algorithm; Part II KalmanAlgorithm; Part III Tuning of PI- and PID-Controllers.Instruments Controlsystems, 1973, №10, p. 57-59; №11, p. 55-59; №12, p. 41-43.

[8] Бабаянц А.В, Коневцов В.А. Идентификация динамических характеристик процессов микробиологического синтеза с помощью УВК.Автоматика и телемеханика, 1982, №3, с. 79-86.

[9] Коневцов В.А. САПР цифровых САУ. Концепция: Монография. Псков: Издательство ППИ, 2011. - 256 с.

[10] Takahashi Y., Chan C.S., Auslander M.D. Parametereinstellung bei linearer DDC-Algorithmen .Regelungstechnik und Prozessdatenverarbeitung, 1971, №6, s.237-244.

[11] Коневцов В.А. САПР цифровых САУ. Концепция: Моногрфия.Псков, Издательство ППИ, 2011. - 256 с.

[12] Коневцов В.А. САПР цифровых САУ. Концепция: моногрфия. - Изд-е второе, дополн. и испр. - Псков: Издательство ПсковГУ, 2012.-307 с.

[13] [3]. Коневцов В.А. САПР цифровых САУ. Концепция: моногрфия. - Изд-е третье, дополн. и испр. - Псков: Издательство ПсковГУ, 2013-317 с.

[14] Коневцов В.А., Казаченко А.П., Литвинова Л.М., Бунин А.Б. Модифицированные средства цифрового 
управления.- М.: Информприбор, Каталог Государственной Системы Приборов СССР, 1987, том 4, вып. $10,11,12$, с. 112.

[15] John Karl-Heinz, Tiegelkamp Michael SPS-Programmierung mit IEC 61131-3 .- Springer - Verlag Berlin Heidelberg 4. Auflage, 2009, s.402.

[16] Konevtsov V.A., Verteshev S.M., PoletaevI.A. Eigenschaften von Complex SDSDC // European Science and Technology: 7th International scientific conference. Germany, Munich 2014, Vol.I, p. 493-497.

[17] Seitz M. Speicherprogrammierbare Steuerungen für die Fabrik- und Prozessautomation.- Fachbuchverlag Leipzig im Carl Hanser Verlag, 3. Auflage, 2012, s. 277.

[18] Speicherprogrammiebare Steuerungen. Teil 3: Programmiersprachen (IEC 61131-3:2003). Deutsche Fassung EN 61131-3:2003.
[19] Tröster F. Steuerungs- und Regelungstechnik für Ingenieure.Oldenburg Verlag München, 3. Auflage, s. 562.

[20] Verteshev S.M., Konevtsov V.A., Poletaev I.A. Methods of Software Developing of Complex SDSDC // European Science and Technology: 4th International scientific conference. Germany, Munich 2013, p. 377-380.

[21] Verteshev S.M. Konevtsov V.A. Poletaev I.A. Softwaremittel der Projektierung von Systemen der digitalen Steuerung // European Science and Technology: 5th International scientific conference. Germany, Munich 2013, Vol. I, p. 501-504.

[22] Wellenreuter G., Zastrow D. Automatisierung mit SPS Theorie und Praxis.- Vieweg + Teubner, 5. Auflage, 2011, s.870. 